\title{
PADRÕES DE DOMINAÇÃO NA SOCIEDADE BRASILEIRA ATUAL: REGRESSÃO DEMOCRÁTICA
}

\author{
Lia Mara Silva Alves* \\ Jânio Pereira da Cunha**
}

\section{RESUMO}

O trabalho tem como objeto de estudo a democracia e o vínculo de dominação no regime democrático representativo. Tem como objetivo geral analisar a democracia brasileira à luz de críticos da teoria democrática moderna, demonstrando o modo como a democracia atual expressa um discurso antidemocráticos e como o povo está conformado ou inerte em face das desigualdades sociais, supressão de direitos e atos de violência estatais. Realizou-se uma pesquisa bibliográfica. É necessário que haja a união dos setores progressistas e democráticos com o objetivo de reconstrução do Estado Democrático, o que exige, a derrota eleitoral do extremismo político no País.

Palavras-chave: Democracia. Dominação. Regressão. Sociedade. Conformismo.

\section{DOMINATION PATTERNS IN CURRENT BRAZILIAN SOCIETY: DEMOCRATIC REGRESSION}

\begin{abstract}
The object of study of the work is democracy and the link of domination the representative democratic regime. the general objective is analyze Brazilian democracy in the light of critics of modern democratic theory, demonstrating how the current democracy expresses an antidemocratic discourse and how the people are conformed or inert in the face of social inequalities, suppression rights and acts of state violence. A bibliographic search was carried out. It's necessary that there be a union of progressive and democratic sectors with the objective of reconstructing the Democratic State, which requires the electoral defeat political extremism in the country.
\end{abstract}

Keywords: Democracy; Domination; Regression; Society; Compliance.

\section{INTRODUÇÃO}

O estudo da democracia tem curso em diversas pesquisas científicas e, na conjuntura atual do governo brasileiro, protagoniza a investigação sob relatório. Especificamente, a

\footnotetext{
${ }^{1}$ *Mestranda em Direito pelo Centro Universitário Christus (Unichristus). Especialista em Docência em Educação a Distância pela Universidade de Fortaleza (UNIFOR). Graduada em Direito pela Unifor. E-mail: liamry@hotmail.com.

2***Professor do Mestrado em Direito do Centro Universitário Christus (UNICHRISTUS). Professor do Curso de Direito da Universidade de Fortaleza (UNIFOR). Doutor em Direito. Lattes: http://lattes.cnpq.br/429457111736595. Email: janiopcunha@hotmail.com
} 
investigação consiste na democracia e o vínculo de dominação no regime democrático representativo.

O trabalho tem como objetivo geral analisar a democracia brasileira à luz de críticos da teoria democrática moderna, em especial ao lume da teoria do elitismo do poder, por intermédio de seus principais fundadores - Mosca, Pareto e Michels - que defendem a ideia de que o povo, na democracia contemporânea, é um sujeito político passivo, porquanto a participação popular fica restrita ao momento da escolha dos representantes que efetiva e realisticamente exercem o poder no Estado. O ensaio intenta demonstrar o modo como a democracia atual expressa um discurso e um argumento antidemocráticos e como o povo está conformado ou inerte em face das desigualdades sociais, supressão de direitos e atos de violência estatais.

Com efeito, o artigo, no primeiro momento, descreve a teoria elitista da democracia, mostrando que o regime democrático possui diversos desafios e apontando a maneira de a representatividade reduzir a soberania popular ante um regime político considerado do povo, mas que se realiza apenas no instante da efetividade do voto. Uma democracia avançada, no entanto, não há que ser reduzida simplesmente à franquia do sufrágio universal.

Observa-se que uma parcela minoritária da elite não concorda com o campo popular ou com os diálogos e tomadas de decisões da população, uma vez que ambos os segmentos possuem interesses diferentes e, não raro, opostos. A minoria ora mencionada defende, em regra, interesses privados, e não os da coletividade, e, com isso, percebe-se o agravamento das desigualdades político-sociais.

No segundo momento, o escrito cuida da passividade da sociedade e das instituições em consequência de opressões e inibições no terreno político, destacando o jeito como a sociedade se submete à dominação de uma minoria. No módulo seguinte, concede-se ênfase ao momento negativo ora experienciado pelo Brasil, quando o atual Presidente da República, Jair Bolsonaro, diretamente ou por meio de autoridades governamentais - e, seja expresso, conforme jamais ocorrido - faz discursos públicos e pratica atos autoritários contra os direitos humanos e ameaçadores à própria condição democrática e às instituições representativas da democracia liberal, tais como o Parlamento e o Supremo Tribunal Federal.

Verifica-se que a seara popular permanece, em grande medida, desorganizada, passiva e tolerante ante a "regressão antidemocrática" (AVRITZER, 2019) no País, fato esse que facilita a redução e a revogação dos direitos individuais, sociais e políticos dos cidadãos. 
Em sendo assim, é perceptível a noção que instituições, criadas para atender aos interesses da maioria da sociedade e impedir retrocessos sociais, estão tomando decisões em favor dos interesses e privilégios das elites dominantes.

A modo de remate, o segmento posterior e último reúne as contradições e paradoxos do regime democrático contemporâneo e, em específico, explana discursos e diálogos no tocante aos problemas do atual regime democrático no Brasil.

\section{ELITISMO DEMOCRÁTICO}

Notória é a ideia de que democracia, em seu sentido etimológico, significa o governo do povo, em que este é o soberano e toma diretamente as decisões políticas. Por outro lado, tem-se a democracia representativa, vinculada ao processo eleitoral, em que se visualiza a soberania do povo, basicamente, no momento do voto, como é exemplo o regime político brasileiro. Evidencia-se que a característica básica das democracias modernas e contemporâneas, depois da clássica experiência direta ateniense, é a da representatividade política. É, teórica e constitucionalmente, o governo do povo (titular do poder) e para o povo (receptor dos bens), mas realística e substancialmente, o regime pelo povo, porquanto, em regra, as deliberações políticas sobre os aspectos fundamentais da sociedade não são tomadas diretamente pelos cidadãos.

A despeito da contradição ou paradoxo da ideia democrática original em relação à democracia real, os defensores da representatividade política justificam o argumento de que o modelo de democracia direta da Antiguidade, praticado na Ágora, é impossível de ser efetivado nos Estados atuais, pois, além de muitos países hoje possuírem grandes extensões territoriais e milhões de habitantes, não seria factível - por isso, não produtivo - reunir todos os cidadãos em um espaço público para decidir diretamente os assuntos de interesse da coletividade.

A respeito dessa situação, tem-se "[...] o fato de que nenhum dos regimes hoje aceitos como democráticos, o povo realmente governa. As decisões são tomadas por uma minoria fechada, via de regra mais rica e mais instruída do que [...] cidadãos comuns" (MIGUEL, 2014, p. 28). Mencionado autor ressalta, ainda, que pessoas com certo grau de instrução, com bens materiais e culturais, tentam demonstrar que possuem uma capacidade superior e que, por isso, estão habilitadas a resolver conflitos políticos de um modo melhor do que os cidadãos comuns. 
Portanto, enormes são os desafios que a democracia ora transporta, e estes estão principalmente ligados aos interesses de pessoas e grupos em circunstâncias de vida em sociedade. Problemas são visualizadas na democracia representativa desde o instante em que se observa o distanciamento entre os representantes e os representados. Assim, a despeito de a democracia desejável pressupor o exercício do poder soberano pelo povo, a democracia agora em decurso se perfaz por meio da transferência de poder, via mandatos eletivos. Efetivamente, divisa-se que a minoria governa e a maioria é governada, pois as decisões políticas são fundamentalmente tomadas por um grupo dominante, chamado de elites políticas por Gaetano Mosca, Vilfredo Pareto e Robert Michels. Advirta-se, por favorável o instante, que esses teóricos são contrários aos movimentos democráticos e ao exercício direto da soberania pelos cidadãos, sob o pretexto de que sempre haverá uma minoria mais capacitada para governar.

Na explicação de Luís Felipe Miguel, para os teóricos elitistas do poder, inclusive o seu principal herdeiro e mais influente autor da teoria democrática dominante na contemporaneidade, Joseph Schumpeter (1961),

[...] sempre vai haver desigualdade na sociedade, em especial a desigualdade política. Isto é, sempre existirá uma minoria dirigente e uma maioria condenada a ser dirigida, o que significa dizer que a democracia, enquanto "governo do povo", é uma fantasia inatingível. Pois é exatamente esta visão que, sobretudo a partir da teoria de Schumpeter, publicada nos anos 1940, se torna a base da tendência dominante da teoria democrática - e penetra profundamente na concepção corrente sobre a democracia. (MIGUEL, 2014, p. 31).

O pensamento elitista afirma que sempre haverá um grupo mais competente para governar e, com efeito, a desigualdade política entre os cidadãos é algo natural e inextinguível. Miguel (2002, p. 456) assenta a reflexão conforme a qual, para um pensador liberal clássico como Alex de Tocqueville, “'igualdade' e 'democracia' eram quase sinônimos. Não é possível haver democracia sem igualdade; e a igualdade leva necessariamente à democracia." Verifica-se, no entanto, que, à luz da teoria elitista do poder, a igualdade é concretamente impossível e, assim, um regime fictício ou virtual. Em outras palavras, para os elitistas, “[...] sempre haverá uma minoria dirigente e uma maioria condenada a ser dirigida, o que significa dizer que a democracia, enquanto 'governo do povo', é uma fantasia inatingível" (MIGUEL, 2020).

No grupo político dominante, é perceptível a vontade de dominância política sobre os membros da sociedade, sob a crença de que possui maior capacidade e mais discernimento 
para governar do que a maioria dos cidadãos. Além disso, o elitismo antidemocrático defende a ideia de que a participação do povo na política é perigosa, porquanto é susceptível de conduzir a uma tirania da maioria contra as minorias.

O coordenador do Grupo de Pesquisa sobre Democracia e Desigualdade da UnB (MIGUEL, 2014) menciona alguns pensadores como Nietzsche e Ortega y Gasset que corroboram, em suas obras, a teoria elitista do poder, ressaltando que o governo deve ser exercido por aqueles com "vontade de poder", dado que possuem capacidade e intelecto mais desenvolvidos, de tal maneira que as massas devem ser comandadas pela minoria.

Na perspectiva de Mills (1962, p. 25), a elite é o grupo dominante, por ser detentor de poder, bens e posição moral e social superiores. Consoante ele ensina,

\begin{abstract}
A elite que ocupa os postos de comando pode ser considerada como constituída de possuidores do poder, da riqueza e da celebridade. Estes podem ser considerados como membros da camada superior de uma sociedade capitalista. Podem também ser definidos em termos de critérios psicológicos e morais, como certos tipos de indivíduos selecionados. Assim definida, a elite, muito simplesmente, é constituída de pessoas de caráter e energia superiores.
\end{abstract}

Miguel (2002) expressa, ainda, o fato de que Vilfredo Pareto se utilizou da Química para explicar o seu modelo elitista de ação política na sociedade. O Teorista da democracia elitista acentua que as ações humanas têm caráter irracional. E acrescenta: “Aqui, é possível inserir o conceito de elite. Pareto afirma que elite é o nome dado ao grupo de indivíduos que demonstram possuir o grau máximo de capacidade, cada qual em seu ramo de atividade" (MIGUEL, 2002, p. 493).

Pareto (1987) pugna pela existência de uma elite que governa e outra não governante, mas exprime haver uma rotatividade entre elas. Nesse ponto, o Autor francês (sociólogo que atuou na Itália) lança a chamada "lei de circulação" das elites. Em outras palavras, "Por uma lei de grande importância, e que é a razão principal de muitos fatos sociais e históricos, essas aristocracias não duram, mas se renovam continuamente. Temos assim um fenômeno que se poderia chamar de circulação das elites" (PARETO, 1987, p. 73).

Já Mosca, conforme Miguel (2002, p. 495), tem argumentos assemelhados aos de Pareto, embora de maneira mais sutil. "Para ele, o domínio da minoria sobre a maioria é uma constante universal". Isso significa a existência de uma classe dominadora dirigente como natural e, por isso, inevitável. E a razão disso é que, ressalta Mosca, o grupo dominante, a minoria, é organizada, e a minoria é, por natureza, desorganizada. 
De acordo com Miguel (2002), ao estudar os teóricos em seu artigo, apesar da linha similar de pensamento entre eles, dado que defensores do elitismo antidemocrático, Pareto e Mosca divergem em alguns pontos, pois, enquanto aquele se preocupava com as qualificações e habilidades da elite, em contrapartida, Mosca não partia dessas premissas, mas sustentava que a minoria organizada se sobrepõe às maiorias. Para Mosca, nas sociedades organizadas, existem duas categorias de pessoas - governantes e governados. A classe dos governantes, sempre quantitativamente menor de pessoas, “[...] desepeña todas las funciones políticas, monopoliza el poder y disfruta de lasventajas que van unidas a él” (MOSCA, 1992, p. 106). A segunda, numericamente maior, “[...] es dirigida y regulada por laprimera de uma manera más o menos legal [...]" (IBIDEM, p. 106). Mosca, por conseguinte, frisa Miguel (2002), não concordava com a ideia de levar, por exemplo, um operário ao poder. Esse discurso, entretanto, é altamente conservador e preconceituoso, na medida em que submete a xeque valores e princípios essenciais à democracia moderna.

Já no tocante ao pensamento do terceiro teórico clássico da teoria das elites, Robert Michels, consoante Miguel (2002), manifestava apreço pelo movimento operário. Miguel, no artigo intitulado "A Democracia Domesticada: Bases Antidemocráticas do Pensamento Democrático Contemporâneo", deixa claro que Pareto e Mosca teorizaram a respeito da dominação do poder pelas minorias, mas não julgaram, e avaliavam, empiricamente, as ideias elitistas em relação a casos concretos.

Michels se propôs, no entanto, analisar um caso, qual seja, os partidos políticos, e, com amparo nele, fazer inferências gerais e abstratas para a dominância social e política em outras instituições. Os achados de Michels o fizeram entender que, para resolver assuntos públicos e políticos, era necessária a organização da minoria capaz de operar decisões para as massas, e que a maioria não conseguia se organizar. Ele compreendeu, igualmente a Gaetano Mosca, que era necessário um grupo organizado, implementando métodos e procedimentos de organização.

A ideia central da doutrina elitista de Michels descansa na assim chamada, pelo autor, de "lei de ferro da oligarquia", segundo a qual "[...] há uma tendência oligárquica em todas as organizações, que nasce de uma necessidade prática e inevitável da própria organização" (CUNHA, 2019, p. 28). Para o autor, o desenvolvimento de "oligarquias no seio das mais variadas formas das democracias é de caráter orgânico, ou seja, é uma tendência 
necessariamente subjacente a toda e qualquer organização, seja ela socialista ou mesmo libertária" (MICHELS, 2001, p. 433)

Vê-se, de efeito, que Michels idealizou a burocratização para ter a eficiência da organização. Estabelecida aquela, o quadro de funcionários começava a se formar e, assim, observou-se que novos movimentos e interesses começavam a surgir, e, com efeito, um simples operário estaria habilitado a, dentro dessa organização, tornar-se um líder político. De acordo com Miguel (2002, p. 498), Michels iguala o grupo de uma minoria dominante a uma oligarquia. E, por essa razão, "Para Michels, [...] não há distinção entre líder político e burocratas, todos sendo igualmente pessoas que se beneficiam da estrutura partidária e, portanto, oligarcas" (IBIDEM, p. 498).

Por meio dessa organização, existe uma minoria dirigente e, por conseguinte, concluiu o autor que só à minoria era dado governar. Para ele, a lei da dominância burocrática nas organizações é regra permanente e inviolável, pois, mesmo que se prescrevam leis para impedir a "[...] dominação dos dirigentes, o que se verifica é que pouco a pouco as leis vão vacilando, mas não os dirigentes" (MICHELS, 2001, p. 426)

Miguel (2002, p. 497) resume o pensamento de que a crítica de Michels “[...] tocou em um ponto crucial para a implementação da democracia, que é a relação entre representantes e representados. Sua teoria é útil para analisar o desgaste atual dos partidos políticos [...].” Procede-se a lábil referência à atual situação do Brasil, onde existem inúmeras agremiações partidárias, em que os representantes fundam agremiações ou se transferem para outros partidos, em razão de interesses particulares ou de suas bases eleitorais. ${ }^{3}$

Retornando à discussão da teoria das elites, Michels faz essa reflexão sobre a democracia representativa e a relação de seus representantes e representados. Ele ensina que sempre vai existir um agrupamento dominante, pois, seja o líder de uma agremiação partidária, um funcionário desse grêmio ou apenas um membro de um partido, tal grupo se beneficia em pensar nos seus interesses, esquecendo-se do bem comum. Miguel contesta a teoria elitista, ponderando que "[...] a doutrina elitista é apenas uma justificação ideológica da desigualdade política" (MIGUEL, 2014, p. 142) e objetiva “[...] neutralizar aqueles que reivindicam um regime mais participativo e igualitário" (IDEM, 2002, p. 506).

\footnotetext{
${ }^{3}$ O Presidente da República do Brasil, Jair Bolsonaro, deixou o seu partido e, conforme o site do g1.globo ${ }^{3}$ (2019), "se filiou ao PSL em 2018 para disputar eleição. Crise no partido foi desencadeada após atrito." Aqui se manifesta claramente a divergência de interesses entre o Chefe do Executivo federal e o partido pelo qual foi eleito.
} 
Cabe trazer a lume o pensamento de Joseph Schumpeter (1961), receptor da influência de Pareto e um dos teóricos e representantes do elitismo democrático na versão formal e concorrencial, e opositor radical da doutrina clássica da democracia, que prima pela defesa da ideia do exercício da soberania política diretamente pelo povo. Ele pondera que o “[...] bem comum" é passível de ser diferente para cada pessoa. Em linhas gerais, Schumpeter (1961) propõe que as pessoas não sabem determinar o que é melhor para elas em relação aos aspectos políticos.

A respeito da reflexão de Joseph Schumpeter sobre a (ir)racionalidade das massas e a perspectiva formal de democracia simplesmente como um instrumento político de escolha dos governantes, comparando-a a um mercado de votos disputados pelas elites, são precisas as ponderações de Avritzer (2012, p. 107-108):

O autor de Capitalismo, Socialismo e Democracia não apenas propõe que a
democracia seja considerada um método, como também ressalta sua característica de
método de produção de governos. Ao discutir a forma como os governos são
produzidos, Schumpeter propõe a superação do empecilho provocado pela
irracionalidade das massas, através da limitação da sua participação na política ao
ato da produção de governos, isto é, ao voto. Todas as demais atribuições do
governo capazes de gerar algum nível de racionalidade política passam a fazer parte
dos encargos das elites. Essas últimas ao competir livremente pelo voto seriam
capazes de assegurar, de forma semelhante à livre competição no mercado, o
prevalecimento da racionalidade política.

O autor defende a noção de que a massa é sempre manipulada pela propaganda política, que existe uma negação da possibilidade de soberania popular e que o povo não possui "capacidade" nem "vontade" para participar ativamente dos assuntos políticos. Dessa maneira, a maioria da sociedade não ostenta o nível de consciência que a política exige e se transforma, por assim dizer, em "massa de manobra" da retórica de políticos.

Para elucidar ainda mais o pensamento de Schumpeter, Miguel (2002, p. 501) pontua que, para o autor, as pessoas “[...] são egoístas, incapazes de se preocuparem com os interesses coletivos (mesmo quando estes as afetam). Ou seja, não adianta mudar as instituições, já que a causa da apatia e da desinformação não está nelas, mas nos próprios indivíduos". Remansa evidente, portanto, que, na perspectiva da teoria do elitismo democrático, de Schumpeter, o cidadão comum é considerado exclusivamente na condição de agente responsável pela escolha e legitimador das elites governantes por meio do voto. Acresça-se, ainda, a noção de que, para Schumpeter, a teoria clássica da democracia, que relaciona democracia e soberania popular, “[...] seria inadequada, técnica e normativamente por supor a possibilidade da unificação da pluralidade quando, na verdade, só é possível supor 
um procedimento para a convivência entre indivíduos diferentes" (AVRITZER, 2012, p. 105106). E, por esse motivo, o autor "[...] propõe a substituição da ideia da democracia enquanto soberania pela ideia da democracia enquanto método" (IBIDEM, p. 107), contestando a "[...] relação entre democracia e soberania ao transferir a fundamentação da democracia do conteúdo substantivo da vontade popular para o método de acordo com o qual decisões distintas são tomadas [...]" (IBIDEM).

Percebe-se da análise dos argumentos das teorias do elitismo democrático um robusto componente antidemocrático e preconceituoso contra a ideia clássica de democracia, a qual pressupõe a soberania do povo. O pano de fundo das correntes elitistas, no entanto, parece ser justificar e legitimar as desigualdades sociais e a distribuição assimétrica do poder no Estado, e, por conseguinte, manter um sistema político que interdita a participação popular nas questões centrais e, com isto, evita-se submeter à discussão e à deliberação públicas pelos próprios cidadãos a repartição por demais desigual do poder político e dos bens materiais na sociedade, mantendo, assim, os bens, direitos e privilégios das elites detentoras do poder político no Estado.

Miguel (2014, p. 151) acentua que a “[...] democracia é um projeto sempre inacabado, que exige o combate permanente contra as formas de dominação e desigualdade que se produzem no mundo social", principalmente em países com problemas políticos e sociais estruturais graves e históricos como os que acometem as sociedades da periferia do capitalismo, como é o caso da brasileira. De fato, conforme Miguel (2014), as democracias atuais são marcadas por uma profunda desigualdade social e política e, por isso, conservam, também, um potencial subversivo, inclusive para permitir um aprofundamento dos valores fundamentais da democracia representativa.

Destaque-se, para remate deste segmento, a ideia de que a possibilidade de ampliação e aprofundamento das bases sociais e políticas de uma democracia mais substantiva ocorreu durante o governo do ex-Presidente Luís Inácio Lula da Silva, no qual houve a conquista de mais direitos sociais e coletivos pelos cidadãos e a efetivação dos já previstos na Constituição vigente. Na última eleição presidencial, todavia, o Brasil imergiu em um retrocesso democrático, que levou a uma grande apatia social e passividade política do povo brasileiro. Essa matéria, porém, é escoliada na seção imediatamente seguinte.

\section{PASSIVIDADE DA SOCIEDADE BRASILERA E DAS INSTIUIÇÕES REPRESENTATIVAS}


Desde a vigência da Constituição de 1988, verifica-se haver instituições democráticas com uma série de limites. Este processo foi lindado por um grupo dominante, isto é, uma elite que continua tendo muito poder e influência, mas que, em grande medida, permitiu um espaço para o povo ser ouvido na política. A “democracia é complexa”, ensina Luis Felipe Miguel, e um bem difícil de ser conquistado e consolidado, mas sobradamente frágil, principalmente em sociedades marcadas por meios políticos autoritários, antiliberais e antipopulares, e, nesse sentido, a história nacional é exemplar, na medida em que a institucionalidade democrática foi interrompida várias vezes por golpes de Estado.

Tanto é verdade que o pacto constitucional de 1988, que garantiu a estabilidade política e social no Brasil, por quase três décadas - um verdadeiro milagre democrático começou a ser desfeito quando as elites dominantes não aceitaram mais os resultados das escolhas dos governantes e romperam com as regras do jogo democrático.

Relembre-se de que, em meados de 2014, ocorreu outra tentativa de derrotar as experiências de governo de centro-esquerda nas urnas, por meio de uma campanha eleitoral marcada por disputa acirrada entre os dois adversários políticos históricos - PT versus PSDB - quando as eleições ocorreram nos limites das regras do jogo político decisório. No pleito, a esquerda brasileira venceu as eleições de 2014 com a reeleição da então presidente Dilma Rousseff. Considerando a quarta vitória da esquerda no País, parte da direita brasileira, oposição derrotada, no entanto, começou a colocar em xeque o resultado eleitoral, inclusive contestando a vitória de Roussef na Justiça Eleitoral e passando a obstruir fortemente a governabilidade do Executivo federal, por meio de ações políticas no Parlamento e nos meios de propagação coletiva.

A respeito das eleições de 2014 e do não aceite do resultado eleitoral pelos derrotados nas urnas, é providencial se transcrever a síntese de Souza Neto (2002, p. 54-55):

Encerrada a contagem dos votos, o candidato derrotado, Aécio Neves, em
telefonema à presidente reeleita, desejou-lhe sucesso e ressaltou que 'considerava a
maior de todas as prioridades unir o Brasil'. Aparentemente, a polarização política
não havia destruído o elemento básico do sistema democrático: o reconhecimento,
também por parte dos derrotados, de que os eleitos devem governar. Se o resultado
das eleições não é aceito, é o próprio processo eleitoral e, no limite, o regime
democrático que se deslegitima. Dois meses depois, antes mesmo de o novo
mandato se iniciar, o tom de Aécio se alteraria de forma drástica: 'Os detentores do
poder usaram despudoradamente o aparato estatal para se perpetuarem no comando'.
A manifestação foi feita no contexto da impugnação do resultado das eleições por
meio da Ação de Investigação de Mandato eletivo (AIME) no 761 , proposta pela
Coligação Muda Brasil, que havia tido Aécio Neves como candidato. [...] Com o não
reconhecimento do resultado das urnas, fragilizava-se um dos elementos 
fundamentais do regime democrático: a expectativa generalizada de que o poder será exercido por quem ganhar eleições.

O momento fulminante de interrupção das regras do jogo eleitoral e comprometimento dos princípios democráticos da soberania popular e da representação política, no entanto, ocorreu com a ruptura institucional decorrente do golpe de Estado, chamado, também, golpe "branco" ou "jurídico" (SOUZA, 2016), "parlamentar" (SANTOS, 2017) e "brando" (ARANTES, 2019, p. 124 e 128), em 2016, que cassou o mandato popular da Presidente Dilma Rousseff, sob a falsa ou equivocada justificativa de que a Mandatária teria cometido crimes de responsabilidade.

Ocorre, todavia, que o procedimento de impeachment sem crime de responsabilidade no sistema constitucional brasileiro, isto é, fora das hipóteses previstas na Constituição e leis disciplinadoras, nada mais é do que um violento atentado à democracia e ao Estado Democrático de Direito. Tratou-se, pois, o impedimento da Presidente Dilma de um sofisticado golpe de Estado, agora, não mais com o emprego direto da violência física e uso de armas e tanques nas ruas pelo poder militar, mas sim de manipulação política do instituto constitucional do impeachment para legitimar a ruptura parlamentar contra a democracia e a soberania popular. ${ }^{4}$ Portanto, a roupagem jurídica do impeachment é hoje utilizada como arma política para destituição ilegítima e inconstitucional de Presidentes progressistas e democraticamente eleitos, sendo, por assim dizer, uma verdadeira máscara formal para encobrir os novos golpes de Estado. ${ }^{5}$

$\mathrm{Na}$ realidade, o caso da ex-Presidente Dilma consistiu na quebra da institucionalidade política perpetrada pelas elites dominantes (política, financeira, empresarial, rentista, militar e midiática), com apoio estratégico de instituições judiciárias e ministeriais, em especial, as atuantes na famigerada Operação "Lava Jato", assim como de

\footnotetext{
${ }^{4}$ Golpe parlamentar, na definição de Wanderlei Guilherme dos Santos, é aquele em que ocorre "[...] uma substituição fraudulenta de governantes orquestrada e executada por lideranças parlamentares" (2017, p. 31).

${ }^{5}$ Conforme adverte Cláudio Pereira de Souza Neto, "A simples observância das normas procedimentais não é suficiente para garantir a juridicidade do julgamento do impeachment" (2020, p. 116). Confira-se, também: (KOERNER, 2018).

${ }^{6}$ A acusação de atuação política e ilícita do ex-juiz Sérgio Fernando Moro, em conluio com Procuradores da República, na Operação "Lava Jato" contra a então Presidente Dilma Rousseff e o ex-Presidente Lula, restou comprovada por vários atos arbitrários e ilegais da $13^{\mathrm{a}}$ Vara Federal de Curitiba, que tinha à frente o citado Juiz (interceptação, quebra e divulgação do sigilo telefônico da Presidenta da República; condução coercitiva do exPresidente Lula sem intimação prévia e grampo do escritório de seus advogados de defesa; vazamentos seletivos de delações premiadas; atuação de férias para impedir o cumprimento da ordem de soltura de Lula, entre outros), assim como pelas mensagens divulgadas pelo site The Intercept Brasil e outros meios de comunicação social, em especial, Veja e Folha de São Paulo (SOUZA FILHO, 2020, p. 135 e rodapé n. 214), e, mais ainda, pela decisão judicial da Segunda Turma do STF, que declarou, no dia 23 de março de 2021, em sede do habeas corpus $\mathrm{n}$.
} 
parte das classes médias urbanas ${ }^{7}$ e de setores religiosos mais conservadores e reacionários (ARANTES, 2019; MATTOS; BESSONE; MAMIGONIAN, 2016; MIGUEL, 2018; SANTOS, 2017; SOUZA, 2016; SOUZA NETO, 2020).

Na verdade, a cassação da Presidente Dilma decorreu diretamente de motivação política, e não criminal, dado que inexistiu qualquer conduta ilícita da Mandatária, fato esse reconhecido pela imprensa internacional e, inclusive, pelo principal beneficiário direto do impeachment, o Vice-Presidente Michel Temer, que reconheceu, depois, em entrevista, não ter a então titular do mandato presidencial praticado qualquer crime político, mas, segundo Temer, “[...] havia caído por não ter adotado o programa [do PMDB] 'Uma ponte para o futuro"” (SOUZA NETO, 2020, p. 117, rodapé n. 176). ${ }^{8}$

Em relação ao impeachment da Presidenta Dilma ainda é importante citar as ponderações de Luís Felipe Miguel (2018, ONLINE):

\begin{abstract}
Quando as nuvens do golpe de 2016 já sombreavam o horizonte, a maior parte da ciência política brasileira ainda via nossa democracia como "consolidada". E mesmo hoje, quando o som dos coturnos em marcha alcança nossos ouvidos, muitos ainda se perguntam como pôde ter acontecido o que aconteceu e não vislumbram nenhum projeto além da restauração da ordem que foi derrubada junto com a presidente Dilma Rousseff.[...] Num país como o Brasil, cujas classes dominantes são tão arredias a qualquer diminuição da distância que as separa do resto da população, isto significa uma democracia que, na tentativa sempre frustrada de se afirmar consolidada, nega permanentemente a si mesma. Como o golpe demonstrou de forma cabal, mesmo o programa reformista mais tímido possível, aquele que o PT no poder adotou, foi demasiado.
\end{abstract}

Desde a cassação da Presidente Rousseff, o aprofundamento antidemocrático e a destruição dos direitos e garantias sociais conquistados com a redemocratização e promulgação da Carta Cidadã avançam e abrem caminho para ascensão da extrema direita política brasileira, com a vitória de Jair Bolsonaro, que conquistou o poder por meio de

164493, a suspeição e a parcialidade do referido juiz, determinando a anulação de todos os atos processuais no processo referente ao "triplex do Guarujá".

7 As classes médias, não raro, apoiam as rupturas institucionais na história brasileira por meio de um forte moralismo de natureza "udenista", sob o pretexto de combate seletivo à corrupção política e de defesa de valores conservadores e reacionários na sociedade. Confira: SOUZA, 2016.

${ }^{8}$ O próprio Presidente da Sessão Senatorial de julgamento do impeachment da Presidente Dilma Rousseff, o ministro do STF, Ricardo Lewandowski, classificou, no dia 23 de setembro de 2016, a destituição do mandato de Dilma de tropeço democrático no País: "[Esse impeachment] encerra novamente um ciclo daqueles aos quais eu me referi. A cada 25, 30 anos, no Brasil, nós temos um tropeço na nossa democracia" (IMPEACHMENT, 2016). (Grifou-se). No mesmo sentido é o entendimento recente do ministro Luís Roberto Barroso: "O ministro do Supremo Tribunal Federal (STF) e presidente do Tribunal Superior Eleitoral (TSE), Luís Roberto Barroso, afirmou, nesta segunda-feira [05.07.2021], que 'não deve haver dúvida razoável de que' a ex-presidente Dilma Rousseff 'não foi afastada por crimes de responsabilidade, nem por corrupção, mas, sim, foi afastada por perda de sustentação política'. Barroso seguiu o raciocínio completando que 'afastá-la por corrupção depois do que veio, do que se se seguiu, seria uma ironia da história"” (POMPEU, 2021). 
campanha baseada em discursos de ódio e violência contra adversários e minorias da sociedade (LGBTQIA+, negros, indígenas, quilombolas), considerados inimigos, e não como cidadãos e opositores legítimos na arena política democrática ${ }^{9}$, assim como na divulgação massificada de fake news pelas redes sociais, inclusive por meio de robôs, e uma pauta moral conservadora, reacionária e religiosa. ${ }^{10}$

Especificamente, em relação às notícias falsas, seja expresso, en passant, que as fakes News, recorrentemente, indicam como a opinião das pessoas é capaz de mudar rapidamente e de que modo estas têm o poder de persuadir a sociedade, principalmente tendo em vista que, não raro, os próprios cidadãos não buscam aferir a veracidade das matérias veiculadas nas redes sociais e, acriticamente, as recepcionam como informações reais e, assim, ocorre de serem eles induzidos a tomar decisões carentes de uma reflexão racional e séria quanto ao processo eleitoral e seus principais agentes políticos.

O golpe de 2016 e a ascensão da extrema direita ao poder central contribuíram para a desmobilização dos movimentos sociais, levando a sociedade a uma espécie de acomodação social e passividade política. Na realidade, o pós-golpe e a eleição de Jair Bolsonaro ampliaram o descrédito da sociedade perante as instituições representativas e aos políticos, fato esse que colaborou para recepção do discurso moralista e anticorrupção da extrema direita contra o sistema político vigente, à política e às instituições democráticas.

No tocante à participação popular atualmente no Brasil, Miguel (2016) assinala que alguns teóricos sustentam que o Brasil vive uma "semidemocracia", pois o regime eleitoral só permite a soberania popular por meio do voto e, no máximo, mediante os institutos da democracia participativa (plebiscito, referendo e iniciativa popular). Estes, entretanto, também estão interditados, seja pelos obstáculos normativos para efetivá-los, seja pelo controle das classes dominantes da participação direta dos cidadãos na esfera política. E o engajamento

\footnotetext{
${ }^{9}$ Leonardo Avritzer, com base no livro Como as democracias morrem, de autoria de Steven Levitsky e Daniel Ziblatt, publicado no Brasil pela Editora Zahar, em 2018, destaca dois elementos que caracterizam condutas antidemocráticas e que se harmonizam ao Brasil atual: "[...] o fraco comprometimento com resultados eleitorais e a tendência a considerar a oposição desleal ou inimiga" (AVRITZER, 2019, p. 57, rodapé n. 6).

${ }^{10}$ Lembra Leonardo Avritizer: "Por fim, não temos como deixar de discutir a ação dos atores neopentecostais durante o processo eleitoral de 2018. Aqui, apareceu de forma inédita uma associação entre valores conservadores, ação religiosa e meios digitais ao longo da campanha de Jair Bolsonaro. [...] uma campanha [...] em que o candidato [...] se valeu intensamente do aplicativo de troca de mensagens WhatsApp, uma das formas mais fechadas de comunicação na internet. Foi lá que se associaram religião e notícias falsas (as fake News), e por meio desse aplicativo circularam informações sobre o assim chamado 'kit gay' - associado ao candidato do Partidos dos Trabalhadores, Fernando Haddad -, que Bolsonaro já havia tentado disseminar, de forma não exitosa, em sua entrevista de agosto no Jornal Nacional. [...]. [...] a informação falsa circulou de forma intensa tanto nas igrejas neopentecostais quanto em grupos de WhatsApp, ajudando a forma opinião contrária ao candidato do Partido dos Trabalhadores" (IBIDEM, p. 131-132).
} 
popular ficou ainda mais complexo e difícil com o governo extremista de Jair Bolsonaro, no qual, claramente, se verifica a "[...] concentração do poder, diminuição da sensibilidade às demandas populares, retração de direitos e ampliação da coerção estatal” (MIGUEL, 2016, ONLINE).

Advirta-se para a noção de que, nos dias atuais, a passividade da sociedade manifesta-se de modo paradoxal, porquanto há muita interação virtual nas redes sociais, mas não se exercem concretamente atos e atividades ativas e concretas para fazer frente à escalada de violência e autoritarismo do Estado e, em especial, das autoridades federais contra movimentos e agentes sociais e políticos, bem como em face de instituições de ensino, pesquisa e extensão - as universidades.

Em tempos de pandemia (2020-2021), observa-se que Jair Bolsonaro desafia, frequentemente, o Estado Democrático de Direito no Brasil e as instituições representativas, forçando seus limites e desrespeitando à Constituição e a legislação, inclusive as normas sanitárias de combate ao coronavírus e proteção das pessoas.

O ideal democrático não aceita que preceitos e elementos básicos de Estado democraticamente avançado sejam retraídos, como, num exemplo, os direitos individuais e coletivos, notadamente as liberdades públicas de pensar e expressar o pensamento, de reunião de protesto político em face dos governantes.

É consabido, porém, o fato de que as instituições governamentais no Brasil funcionam cada vez mais a serviço dos interesses dos grupos políticos dominantes e, em contrapartida, se omitem em relação às camadas mais vulneráveis da sociedade, produzindo o agravamento da desigualdade social, pobreza e miséria no País e, consequentemente, a volta de uma das mais hediondas modalidades de desrespeito à dignidade da pessoa humana: a fome. O fato é que o Estado brasileiro, deliberada e conscientemente, não apenas renunciou à luta contra as mazelas sociais que acometem historicamente o País, mas, com atos e omissões, as amplia com rapidez, inclusive em uma das fases mais dramáticas da história da humanidade - pandemia do Covid-19.

É verdade que, ante o contexto sanitário e de desilusão política relativamente à democracia representativa, não se tem uma organização popular que vá às ruas das cidades brasileiras para protestar e lutar contra os retrocessos sociais, políticos e ambientais levados a cabo pela política destrutiva do governo Bolsonaro. A respeito da apatia política, pondera Chaui (2000, p. 479): 
As pessoas que, desgostosas e decepcionadas, não querem ouvir falar em política, recusam-se a participar de atividades sociais que possam ter finalidade ou cunho político, afastam-se de tudo quanto lembre atividades políticas, mesmo tais pessoas, com seu isolamento e sua recusa, estão fazendo política, pois estão deixando que as coisas fiquem como estão e, portanto, que a política existente continue tal qual é. A apatia social é, pois, uma forma passiva de fazer política.

\section{CONTRADIÇÕES NO REgIME POLÍTICO CONTEMPORÂNEO DEMOCRÁTICO}

O principal protagonista da democracia deve ser, normativa e concretamente, o povo. No caso do Brasil, malgrado a previsão expressa do princípio da soberania popular, na prática, os cidadãos continuam fundamentalmente alijados das decisões políticas fundamentais na sociedade. E, nos últimos anos, com a chegada ao poder de Michel Temer e, principalmente, com a vitória do extremista Jair Bolsonaro, além dos ataques aos fundamentos do Estado Social brasileiro, se observa que o alicerce da democracia começou a ter rachaduras profundas no tocante aos direitos e garantias individuais e políticos dos cidadãos.

O Presidente da República, Jair Bolsonaro, faz constantemente discursos antidemocráticos e traz as forças armadas para atuar como agente central do regime político e da governabilidade no âmbito federal, alijando, assim, os civis da seara política, e concentrando as atividades administrativas e governamentais em representantes militares e também do espectro ideológico da extrema direita política.

Nessa linha, é importante invocar as ideias do jurista e sociólogo fluminense Oliveira Viana, para quem, na perspectiva elitista da democracia, "[...] a realização de um grande ideal nunca é obra coletiva da massa, mas sim de uma elite, de um grupo, de uma classe, que com ele se identifica, que por ele peleja e que. quando vitoriosa, lhe dá realidade e lhe assegura a execução" (1939, p.97).

Nessa nova realidade de retrocesso político no Brasil, a classe dominante postula o argumento de que o governo de Bolsonaro é a melhor opção para defender os interesses do mercado. Há, todavia, uma contradição entre a democracia e um regime que veda a seara popular de participar das decisões políticas, inclusive no tocante às conquistas sociais já obtidas na Constituição e nas leis e efetivadas no plano concreto, mas, no atual governo, restringidas ou eliminadas por meios de reformas constitucionais e legislativas sem qualquer diálogo ou negociação com os principais interessados e atingidos - os cidadãos brasileiros.

Destaque-se o fato de que esse modo de conduzir a máquina pública compromete um dos elementos centrais da democracia, qual seja, a igualdade política dos cidadãos de 
participar, falar e discutir sobre seus bens e direitos fundamentais. Tal fato comprova que as democracias de "baixa intensidade" (SANTOS, 2016) são profundamente assimétricas, dado que acometidas por gritantes desigualdades de classe, gênero, renda, educacional e racial, e que isso afeta diretamente a possibilidade de que as pessoas comuns tenham acesso às esferas do poder.

Essas contradições produzem influxos negativos no funcionamento dos regimes políticos democráticos, como a passividade popular, supressão de direitos individuais e coletivos, sociedade desigual, injusta e precária quanto às possibilidades de desenvolvimento humano, o que pressupõe, não somente, o crescimento econômico, mas também social. Miguel (2018, ONLINE) destaca, entretanto, a opinião de que a democracia

[...] traz, em seu próprio nome, um paradoxo: é o governo do povo, isto é, é o governo daqueles que são governados. Seu princípio é conferir poder a quem não o tem. É um regime que, para ser digno de si mesmo, deve entrar em combate contra todas as formas de opressão e dominação vigentes na sociedade. Talvez o que nos permita alcançar uma democracia mais consolidada não seja a minimização de suas ambições, a fim de não ameaçar os dominantes, mas, ao contrário, a construção de uma sociedade mais igualitária.

Na descrição de Benevides (1998), o veto político dos cidadãos não há de existir na democracia, principalmente nos regimes constitucionais que preveem instrumentos de participação direta da sociedade - como o plebiscito, referendos e iniciativa popular - veículos de aprovação e correção de decisões tomadas pelos governantes. Tais meios, porém, são interditados pelas forças contrárias ao aprofundamento da democracia e à ampliação de direitos.

Adverte Benevides (1998, p.71) para a noção de que a “[...] hostilidade dos parlamentares e dos partidos em relação às consultas populares decorre, portanto, do que eles entendem, reciprocamente, como a hostilidade do eleitorado". As consultas populares, todavia, rompem as barreiras entre o âmbito popular e o Estado, possibilitando a expressão dos argumentos e diálogos da sociedade civil organizada com os atores estatais.

Atente-se, porém, para o pensamento conforme o qual a elite dominante não cria oportunidades para tais iniciativas, pois em seus discursos preconceituosos e, não incomumente, autoritários, assere que o povo não sabe votar nem decidir e, com efeito, não tem competência para tomar determinadas decisões públicas. Para evidenciar o repúdio antidemocrático à participação popular, em 2019, o atual presidente, Jair Bolsonaro, editou o Decreto n. 9.759/2019 (BRASIL, 2019, ONLINE) que extinguiu os conselhos participativos 
da população, em total desrespeito à ideia democrática de que o povo é o titular e exercente do poder nas sociedades democráticas.

Adite-se o fato de que, em 2018, ao escolher Bolsonaro, os cidadãos expressaram “[...] o sentimento antissistema, que se traduz na rejeição global de todos os partidos tradicionais", isto é, a “[...] insatisfação com todo o sistema político" (SOUZA NETO, 2020, p. 139). Em outras palavras, “Os eleitores votaram não para construir um futuro melhor, mas rejeitar o passado, como se gritasse 'chega'. Resultante de um complexo de 'antissentimentos', a eleição de um extremista caricato foi, para muitos eleitores, um ato de vingança contra tudo e contra todos" (IBIDEM, p. 139).

Existem diversas contradições no regime político democrático contemporâneo, principalmente quando, no Brasil, o Governo Federal emite declarações e pratica atos autoritários que vilipendiam diretos sociais e individuais, entre eles, as liberdades civis e políticas dos cidadãos, como, num exemplo, os ataques às liberdades de expressão e reunião nas universidades públicas por parte de professores e estudantes, assim como às manifestações literárias e artísticas e, o que é ainda mais grave, irracional e criminoso, quando desfecha falas e políticas de ódio e repúdio à ciência e à academia e às medidas sanitárias de combate ao coronavírus e de defesa da saúde e a vida dos brasileiros. Nessa mesma linha antidemocrática, são os atos autoritários de cerceamento à liberdade de imprensa por meio da perseguição aos formadores de opinião pública, tais como jornalistas e youtubers, por intermédio da instauração de inquéritos policiais e ações criminais no Poder Judiciário.

$\mathrm{Na}$ contextura atual, é relevante destacar a noção de que a reduzida intensidade da participação popular e a não utilização dos mecanismos constitucionais de freios e contrapesos - isto é, de controle recíproco entre os Poderes - por parte das instituições parlamentares e judiciárias, colabora significativamente com a "regressão democrática" e abala as "convicções democráticas do cidadão comum" (AVRTIZER, 2019, p. 177) em relação às instituições democráticas.

Assim sendo, o enfrentamento da "regressão democrática" e a redução dos danos provocados pelo governo extremista do Brasil aos direitos e garantias fundamentais dos cidadãos, previstos na Constituição e assegurados nos governos de esquerda (Lula e Dilma) por meio de políticas públicas de inclusão social, redução das desigualdades e eliminação da 
pobreza, miséria e fome - tais como, os programas "Bolsa Família" e o "Fome Zero"11 -, exigem a reorganização do contingentes das forças políticas e sociais progressistas e democráticas no País, sob pena de a desarticulação dos agentes oposicionistas corroborar o regresso antidemocrático pelo qual passa o Brasil, desde o golpe parlamentar de 2016 e a eleição de Jair Bolsonaro.

A respeito da necessidade de articulação entre vários setores sociais e políticos comprometidos com o retorno da democracia no País e a derrota do bolsonarismo autoritário, confiram-se as observações de Cláudio Pereira de Souza Neto:

É fora de dívida que apenas a própria sociedade pode efetivamente garantir que a democracia seja preservada.

$[\ldots]$

Enfatiza-se, sobretudo, a importância de a atividade política considerar a necessidade de se recomporem consensos em torno da estrutura básica do Estado Democrático de Direito. Tais consensos devem ser transversais em relação tanto ao pluralismo político quanto ao pluralismo religioso.

Para enfrentar ameaças graves à democracia, é fundamental congregar direita e esquerda em torno da causa democrática. Não é imprescindível produzir unidades eleitorais entre correntes que, há décadas, disputam os pleitos em polos opostos, o que seria irrealista. O importante é generalizar a compreensão de que o restabelecimento pleno da democracia política possui importância superior à atribuída à realização imediata de outras dimensões dos programas partidários.

$[\ldots]$

Caberá à sociedade pôr fim ao presente momento autoritário e reiniciar um ciclo de desenvolvimento democrático. O principal papel das instituições nacionais [...] é cooperar com a sociedade na preservação da democracia durante a travessia, em que hoje nos encontramos enredados. (SOUZA NETO, 2020, p. 212-213 e 218). (Grifou-se)

Portanto, o projeto coletivo mais importante e urgente hoje no Brasil deve ser a articulação de um amplo e plural movimento político e social com todos os agentes comprometidos com os princípios, valores e regras da democracia e os direitos civis, políticos e sociais das pessoas para derrotar o governo conservador, autoritário e fascista de Jair Bolsonaro $^{12} \mathrm{e}$, assim, os cidadãos brasileiros terem a oportunidade de "[...] escolher um governante que seja comprometido com a democracia” (SOUZA NETO, 2020, p. 217).

\footnotetext{
11 “[...] o processo de diminuição das desigualdades que ocorreu no Brasil começou no governo FHC, mas coube ao governo Lula dar impulso ao processo com sua política de salário mínimo e ampliação dos beneficiários da bolsa família" (BRESSER-PEREIRA, 2015, p. 322).

12 "Bolsonaro sustenta padrões de virulência política com um radicalismo só verificado nos movimentos fascistas do início do século XX. [...]. Um dos elementos do fascismo é a caracterização dos adversários como inimigos a serem combatidos, expulsos ou eliminados. [...]. O bolsonarismo elegeu a esquerda, o PT, os comunistas, o MST e o MTST como inimigos [...]" (SOUZA NETO, 2020, p. 155-157).
} 


\section{CONCLUSÃO}

A democracia representativa nacional enfrenta uma terrível crise política, social, econômica e sanitária, que comprometeu significativamente as bases do Estado Democrático de Direito, em especial, as regras constitucionais do jogo político eleitoral responsáveis por assegurar que os representantes eleitos cumpram, legítima e integralmente, o mandato conferido pelo povo em eleições livres.

A deterioração democrática no País teve início com o golpe de Estado de 2016, que usurpou, inconstitucionalmente, o mandato da então Presidente Dilma Rousseff e outorgou-o ao Vice, Michel Temer. Dois anos depois, a vitória do representante da extrema direita política, Jair Bolsonaro, implantou no Brasil um governo autoritário e antipopular com graves agressões aos direitos e liberdades públicas previstas na Constituição Federal, em especial, os direitos de expressão e manifestação do pensamento, reunião, protesto, crítica, assim como liberdade jornalística, científica e artística.

No plano político, a ideia de democracia como um governo do povo não é mais reconhecida, dado que a premissa orientadora do projeto autoritário e extremista em curso no País é afastar do poder e do gozo dos direitos e bens materiais aqueles considerados como "inimigos" políticos do bolsonarismo e, com efeito, descartáveis, como esquerdistas, feministas, gays, índios, quilombolas e membros de movimento sociais, como, exempli gratia, MST e MTST.

No âmbito dos costumes e mentalidades, tem-se o recrudescimento do moralismo conservador, utilizado pelo governo federal para segurar o apoio de sua base ideológica de sustentação política, principalmente entre religiosos e defensores da chamada família tradicional, por meio da defesa de ideias e projetos morais relacionados à "preservação de valores conservadores e ligados à preservação da família”, como é o caso do famigerado "Escola Sem Partido - [...] criado como homônimo inverso do Escola Sem Homofobia" para "combater à chamada ideologia de gênero" (LACERDA, 2019, p. 191 e 199-200). Na verdade, o "Escola Sem Partido" foi idealizado para contrapor-se às ideias e políticas progressistas de conscientização e respeito à igualdade e à diversidade sexual e de gênero entre os jovens nas escolas.

Verifica-se também que o Governo Bolsonaro é exercido e controlado por um pequeno grupo dominante em prol das classes ricas, poderosos e privilegiadas, que são também as principais beneficiadas pelas reformas constitucionais e também legais que 
destroem ou restringem direitos sociais, trabalhistas e previdenciários dos cidadãos brasileiros.

É oportuno salientar a ideação de que a teoria do elitismo se exprime intensivamente na atual conjuntura do sistema político do Brasil, em que a extrema direita governa o País e orienta-se por ideias e práticas de rejeição à soberania popular, à separação e divisão dos Poderes, e apenas uma minoria dominante governa o Brasil. A retração da democracia brasileira conduziu, em grande medida, as pessoas a um estado de passividade e intensivo sentimento de rejeição à política, aos políticos e às instituições representativas da sociedade, principalmente do Parlamento e dos partidos políticos.

Na seara social, a regressão democrática no País vem eliminando e limitando programas e projetos sociais institucionalizados ou ampliados nos chamados governos de esquerda (2002-2016), o que aprofundou as desigualdades sociais e ampliou o número de pobres e miseráveis e, com efeito, trouxe de volta um dos modos mais cruéis e desumanos de vilipêndio à dignidade humana: a fome.

É, por conseguinte, de todo necessário e urgente que haja a união dos setores progressistas e democráticos com o objetivo central de reconstrução do Estado Democrático de Direito brasileiro, o que exige, antes de tudo, a derrota eleitoral do extremismo político no País.

\section{REFERÊNCIAIS}

ARANTES, Aldo. Em defesa da democracia e da Constituição: (des)constitucionalização e neoliberalismo. In: ARRANTES, Aldo et. al. Por que a democracia e a Constituição estão sendo atacadas? Rio de Janeiro: Lumen Juris, 2019. p. 31-231.

AVRITZER, Leonardo. A moralidade da democracia: ensaios em teorias habermasianas e teoria democrática. São Paulo: Perspectiva, 2012.

AVRITZER, Leonardo. O pêndulo da democracia. São Paulo: Todavia, 2019.

BENEVIDES, Maria Victoria de Mesquita. A cidadania ativa: referendo, plebiscito e iniciativa popular. 3. ed. São Paulo: Ática, 1998.

BEZERRA, Karla; SZWARE, José; ROMÃO, Wagner; VELLO, Bruno. Um decreto contra a participação. Os riscos à democracia no Brasil. Carta Capital - Sociedade, 2019. Disponível em: https://www.cartacapital.com.br/sociedade/um-decreto-contra-a-participacao-os-riscos-ademocracia-no-brasil/. Acesso em: 28 nov. 2019. 
BRASIL. Decreto n. 9.759/2019, de 11 de abril de 2019. Extingue e estabelece diretrizes, regras e limitações para colegiados da administração pública federal. Presidência da República. Brasília. Disponível em: http://www.planalto.gov.br/ccivil_03/_ato20192022/2019/decreto/D9759.htm. Acesso em: 06 abr. 2021.

BRESSER-PEREIRA, Luiz Carlos. A construção política do Brasil: sociedade, economia e estado desde a Independência. 2. ed. São Paulo: Editora 34, 2015.

CHAUI, Marilena. Convite à filosofia. São Paulo: Ática, 2004.

CUNHA, Jânio Pereira da. Democracia e direito: o controle judicial de constitucionalidade da política. Rio de Janeiro: Lumen Juris, 2019.

LACERDA, Marina Basso. O novo conservadorismo brasileiro. Porto Alegre: Zouk, 2019.

IMPEACHMENT foi 'tropeço da democracia', diz Lewandowski. Folha de São Paulo, 29 set. 2016. Disponível em: https://www1.folha.uol.com.br/poder/2016/09/1817948impeachment-foi-tropeco-da-democracia-diz-lewandowski.shtml. Acesso em: 03 abr. 2021.

KOERNER, Andrei. Política, direito e judiciário - centralidade e ambivalência do judiciário na ordem constitucional de 1988. In: HOLLANDA, Cristina Buarque de; VEIGA, Luciana Fernandes; AMARAL, Oswaldo E. do. A Constituição de 88: trinta anos depois. Curitiba: UFPR, 2018. p. 305-328.

MATTOS, Hebe; BESSONE, Tânia; MAMIGONIAN, Beatriz G. Historiadores pela democracia: o golpe de 2016 e a força do passado. São Paulo: Alameda, 2016.

MAZUI, Guilherme; RODRIGUES, Paloma. Bolsonaro anuncia saída do PSL e criação de novo partido. G1 Política, 2019. Disponível em: https://g1.globo.com/politica/noticia/2019/11/12/deputados-do-psl-dizem-que-bolsonarodecidiu-deixar-partido-e-criar-nova-legenda.ghtml. Acesso em: 15 dez. 2020.

MICHELS, Robert. Para uma sociologia dos partidos na democracia moderna. Tradução de José M. Justo. Lisboa: Antígona, 2001.

MIGUEL, Luis Felipe. A Democracia Domesticada: Bases Antidemocráticas do Pensamento Democrático Contemporâneo. Revista de Ciências Sociais. Rio de Janeiro, v. 45, n. 3, p. 483-511, ago. 2002.

MIGUEL, Luis Felipe. Democracia e representação: territórios em disputa. São Paulo: Editora Unesp, 2014.

MIGUEL, Luis Felipe. É hora de barrar o golpe. 2016. Disponível em: https://blogdaboitempo.com.br/2016/03/17/e-hora-de-barrar-o-golpe/. Acesso em: 15 dez. 2020.

MIGUEL, Luis Felipe. Incêndios adormecidos. 2017. Disponível em: https://blogdaboitempo.com.br/2017/01/06/incendios-adormecidos/. Acesso em: 15 dez. 2020. 
MIGUEL, Luis Felipe. O enterro da “democracia utópica”. 2018. Disponível em: https://blogdaboitempo.com.br/2018/02/22/o-enterro-da-democracia-utopica/. Acesso em: 15 dez. 2020.

MIGUEL, Luis Felipe. Oligarquia, democracia e representação no pensamento de Michels. Revista Brasileira de Ciência Política. Brasília, n. 13. p. 137-154, jan./abr. 2014. Disponível em: https://www.scielo.br/pdf/rbcpol/n13/a06n13.pdf. Acesso em: 15 dez. 2020.

MILLS, C. Wright. A elite do poder. Tradução de Waltensir Dutra. Rio de Janeiro: Zahar Editores, 1962.

MOSCA, Gaetano. La classe política: selección e introducción de Norberto Bobbio. Tradução de Marcos Lara. México: Fondo de Cultura Económica, 1992.

PARETO, Vilfredo. Manual de Economia Política. Tradução de João Guilherme Vargas Netto. São Paulo: Editora Nova Cultura Ltda, 1987.

POMPEU, Ana. Barroso: Dilma "não foi afastada por crimes de responsabilidade ou corrupção". Disponível em: https://www.jota.info/stf/do-supremo/barroso-dilma-nao-foiafastada-por-crimes-de-responsabilidade-ou-corrupcao-05072021. Acesso em: 7 jul. 2021.

SANTOS, Boaventura de Sousa. A difícil democracia: reinventar as esquerdas. São Paulo: Boitempo, 2016.

SANTOS, Wanderley Guilherme dos. A democracia impedida: o Brasil no século XXI. São Paulo: FGV, 2017.

SCHUMPETER, Joseph Alois. Capitalismo, Socialismo e Democracia. Tradução de Ruy Jongmann. Rio de Janeiro: Editora Fundo de Cultura, 1961.

SOUZA, Jessé. A radiografia do golpe: entenda como e por que você foi enganado. Rio de Janeiro: Leya, 2016.

SOUZA NETO, Cláudio Pereira de. Democracia em crise no Brasil: valores constitucionais, antagonismo político e dinâmica institucional. São Paulo: Contracorrente, 2020.

VIANA, Oliveira. Idealismo da Constituição. 2. ed. aumentada. São Paulo: Companhia Editora Nacional, 1939. 